\title{
EFFECT OF THE THERMAL MODIFICATION AND NANO-ZNO IMPREGNATION ON THE DETERIORATION OF CARIBBEAN PINE WOOD
}

\author{
Bruno Couto da Silva ${ }^{1}$,Henrique Trevisan ${ }^{2,}$, Rosilei Aparecida Garcia ${ }^{2}$
}

\begin{abstract}
This study aimed to investigate the effect of thermal modification and nano-zinc oxide (nano-ZnO) particle impregnation on the deterioration of Caribbean pine wood under field conditions. Samples were thermallymodified at various temperature levels (control, $180{ }^{\circ} \mathrm{C}, 200{ }^{\circ} \mathrm{C}$, and $220^{\circ} \mathrm{C}$ ). Nano-ZnO impregnation was done with an aqueous solution at 1,5\% in an autoclave under two-steps of pressure and vacuum. Unmodified and thermally-modified, non-impregnated and nano- $\mathrm{ZnO}$ impregnated samples were exposed to deterioration for five months in field tests. A deterioration index was used to evaluate the health condition of the samples. The mass loss and occurrence of termite tunnels in percentage were also determined. The nano-ZnO impregnation improved the resistance of unmodified wood to field-deterioration. The thermal modification at $180^{\circ} \mathrm{C}$, and $200^{\circ} \mathrm{C}$ increased the wood deterioration and nano- $\mathrm{ZnO}$ impregnation did not improve their resistance. Unmodified and $220^{\circ} \mathrm{C}$ modified samples had a lower mass loss by xylophages than other thermal treatments regardless of the nanoparticle impregnation. The nano- $\mathrm{ZnO}$ impregnation decreases the occurrence of termite tunnels in unmodified, $200{ }^{\circ} \mathrm{C}$ and $220^{\circ} \mathrm{C}$-modified samples.
\end{abstract}

Keywords: Deterioration index, mass loss, nano-zinc oxide particle, termite tunnels, wood deterioration.

\section{INTRODUCTION}

Wood is an organic material subject to the action of biotic and abiotic deterioration. Therefore, it is necessary to use products and processes that increase its resistance to deterioration in order to optimize its use, especially when the environmental conditions as in Brazil favor the action of xylophage agents. The biological resistance of wood can be improved through treatments that add characteristics that hinder or inhibit the action of these xylophage organisms (Vidal et al. 2015). Among the treatments used for wood preservation, the most noteworthy are the chemical products (Valle et al. 2013, Vidal et al. 2015) and thermal modification (Salman et al. 2017, Sivrikaya et al. 2015, Tripathi et al. 2014).

CCA(Chromium Copper Arsenate) is the most well-known and most used chemical in the wood preservation industry and accounts for more than $90 \%$ of chemically-treated wood in Brazil (Vidal et al. 2015). Actually, in Brazil, there is no restriction on the use of CCA for the preservation of wood. However, in North America and Europe, its use, mainly due to the arsenic component, has been restricted due to environmental and human health issues, being limited to certain classes of exposure to biological risks that do not involve direct contact with the being such as domestic use. Therefore, the wood preservation sector has been searching for methods that can replace the use of CCA, mainly in applications where the product has been banned.

\footnotetext{
${ }^{1}$ Postgraduate program in Environmental and Forest Sciences, Department of Forest Products. Forest Institute, Federal Rural University of Rio de Janeiro. Seropédica, Brazil.

${ }^{2}$ Professor, Department of Forest Products. Forest Institute, Federal Rural University of Rio de Janeiro. Seropédica, Brazil.

•Corresponding author: hentrevisan@gmail.com
}

Received: 07.05.2019 Accepted: 05.08.2020 
Thermal modification and nanoparticles (e.g. zinc oxide, zinc-borate, silver, copper, and copper-borate) treatments have emerged as alternative treatments to improve biological resistance to wood (Bak and Németh 2018, Lykidis et al. 2016, Marzbani et al. 2015, Taghiyari et al. 2015, Mantanis et al. 2014, Clausen et al. 2011). Several works have reported an increase on decay resistance of wood following thermal modification (Salman et al. 2017, Sivrikaya et al. 2015, Tripathi et al. 2014) but a decrease on the resistance to termite attacks (Trevisan et al. 2014, Salman et al. 2017). Moreover, the literature reports contradictory results about the effect of thermal modification on the resistance of wood to the attack of these insects in laboratory tests (Paes et al. 2015, Pessoa et al. 2006). Previous works also have shown an important effect of nano-ZnO on biological resistance. For example, Clausen et al. (2011) reported an increase of termite mortality (Reticulitermes flavipes Kollar) and a decrease in wood consumption in nano-ZnO-treated Southern yellow pine (Pinus echinata Mill.) wood in laboratory tests. According to Mantanis et al. (2014), nano-ZnO and Boron association inhibited the action of termite species Coptotermes formosanus and the decomposition by xylophagous fungus Trametes versicolor in pine wood. Lykidis et al. (2018) also observed that wood species Fagus sylvatica impregnated with nano-ZnO has shown increased resistance to the termite species Reticulitermes grassei. However, it is not clear whether this also occurs in field conditions or other termite species. In these environments, the biotic and abiotic deteriorating agents interact with each other in the form of synergies and antagonisms which are difficult to reproduce under laboratory conditions. According to Lykidis et al. (2013), nano-ZnO has great potential to be used in wood preservatives, although they emphasize the need of carrying out tests under field conditions. This same reasoning should also be done when considering thermal modification as a process to increase the biological resistance of the wood.

Therefore, this study aimed to investigate the effect of thermal modification and nano-ZnO impregnation on the deterioration of Caribbean pine wood in field tests.

\section{MATERIAL AND METHODS}

\section{Material and thermal modification}

Free-defect samples of $150 \times 75 \times 20 \mathrm{~mm}^{3}$ (length $\times$ width $\times$ thickness) were prepared from a twenty-fiveyears-old Caribbean pine tree harvested from a plantation located in Seropédica city of Rio de Janeiro State, Brazil (Latitude: $-22^{\circ} 44^{\prime} 38^{\prime}$ S, Longitude: $-43^{\circ} 42^{\prime} 27^{\prime}$ W). Samples were conditioned in a climate chamber at $20{ }^{\circ} \mathrm{C}$ and $65 \%$ relative humidity (RH) until mass equilibrium.

Thermal modification treatments were performed in a laboratory muffle furnace from Linn Elektro Therm of $600 \times 600 \times 700 \mathrm{~mm}^{3}$ at three temperature levels $\left(180^{\circ} \mathrm{C}, 200{ }^{\circ} \mathrm{C}\right.$, and $\left.220^{\circ} \mathrm{C}\right)$. Four steps were used for the thermal treatment: (1) heating up to $100{ }^{\circ} \mathrm{C}$ for $2 \mathrm{~h},(2)$ heat increasing from $100{ }^{\circ} \mathrm{C}$ to final temperature $(180$ ${ }^{\circ} \mathrm{C}, 200^{\circ} \mathrm{C}$, and $220^{\circ} \mathrm{C}$ ) for $30 \mathrm{~min}$, (3) thermal modification at the final temperature for $2 \mathrm{~h}$, and (4) cooling for approximately $24 \mathrm{~h}$. The initial moisture content of the samples (before thermal modification) was approximately $12 \%$ (based on the oven-dry weight). Thermally-modified samples were then stored at $20{ }^{\circ} \mathrm{C}$ and 65 $\%$ RH until mass equilibrium. Afterward, thermally-modified woods were separated into two matched groups and one from them was used to nanoparticle impregnation.

\section{Nanoparticle impregnation treatment}

A compact impregnation plant T10 with 4531 of capacity from Wood Treatment Technology (WTT) company was used to nanoparticle treatment. Commercial nano-ZnO particles denominated VP AdNano® $\mathrm{ZnO} 20$, hydrophilic version, with dimensions varying from 20 to $25 \mathrm{~nm}$, from Evonik Industries AG (Essen, Germany) were used for impregnation treatment. A nano-ZnO aqueous solution at $1,5 \%$ was prepared and homogenized with a CanLab mechanical stirrer. This concentration was chosen due to the high cost of nanoparticles. Moreover, low concentrations decrease the viscosity of the solution, which facilitates the impregnation of the nanoparticles in the wood. The sample impregnation was done in a storage tank placed below the autoclave under two steps of pressure and vacuum: (1) application of vacuum at $0,005 \mathrm{Mpa}$ for 10 $\mathrm{min}$, and (2) application of pressure at $0,4 \mathrm{MPa}$ for $15 \mathrm{~min}$. The nano-ZnO-impregnated samples were dried at $40{ }^{\circ} \mathrm{C}$ for $24 \mathrm{~h}$ and then stored at $20^{\circ} \mathrm{C}$ and $65 \% \mathrm{RH}$ until mass equilibrium. The weight of the samples was taken at this condition. 
An experimental design with four temperature levels of thermal modification (ambient or control, $180{ }^{\circ} \mathrm{C}$, $200{ }^{\circ} \mathrm{C}$, and $220^{\circ} \mathrm{C}$ ) and two impregnation groups (non-impregnated and nano-ZnO-impregnated) were used, resulting in eight treatments.

\section{Field tests}

Wood samples of $150 \times 20 \times 20 \mathrm{~mm}^{3}$ (length $\mathrm{x}$ width $\times$ thickness) were installed in a field trial using the randomized complete block design (RDBD) with eight replicates per treatment. Samples were planted until half of its length, remaining exposed to the process of deterioration during five months, from April to September 2017. Inspections were monthly performed to record termite colonization, evidenced by the construction of tunnels along the length of the sample. After five months of exposure in the decay-field, the samples were transported to the laboratory where they were cleaned and then the deterioration level was evaluated according to the criteria shown in Table 1. Afterward, samples were conditioned at $20{ }^{\circ} \mathrm{C}$ and $65 \%$ UR until constant mass. The sample masses were measured at the initial condition (before field test) and after exposure in the field test. The mass losses of the samples were then calculated in percentage.

Table 1: Classification criteria of deterioration levels of wood samples in field tests according to Lepage (1970)

\begin{tabular}{|l|c|}
\hline Health condition & Deterioration index \\
\hline Breakage, almost total loss of resistance & 0 \\
\hline Severe decay or internal attack of termites & 40 \\
\hline Moderate attack of decay or termites & 70 \\
\hline Slight or superficial attack of decay or termites & 90 \\
\hline Healthy, no evidence of the attack & 100 \\
\hline
\end{tabular}

The analysis of the mass loss data was performed in the BioEstat software, version 5.0 (Ayres et al. 2007). The normality of the data was verified by the Lillefors test, followed by an analysis of variances and the comparison of the means by the Tukey's test at the 0,05 probability level.

\section{RESULTS AND DISCUSSION}

The means of the index deterioration and density of the thermally-modified Caribbean pine wood, nonimpregnated, and nano-ZnO-impregnated, after five months in the field test, are shown in Table 2. All samples from all treatments showed evidence of deterioration but at different levels depending on the treatment condition (Figure 1). The $180{ }^{\circ} \mathrm{C}$-modified samples, regardless of the nanoparticle treatment, showed a high deterioration with an average index of 23 and 7 for non-impregnated and nano-ZnO-impregnated samples. On the other side, the action of the xylophages was less intense in the $200{ }^{\circ} \mathrm{C}$-modified samples (non-impregnated and nano-ZnO-impregnated). The nanoparticle treatment provided an index that indicates lower deterioration in the unmodified samples, compared to the other treatments, being, therefore, the most expressive result in this experiment. It is important to emphasize that all treatments presented ruptured samples in the border region between the buried and aerial parts, evidenced by the zero indexes in the minimum value, except in the non-impregnated-220 ${ }^{\circ} \mathrm{C}$-modified and the nano-ZnO-impregnated-unmodified samples (Figure 1). These results, in addition to the previous observations, show that these two treatment conditions were actually the ones that improved the resistance to deterioration because no sample was completely broken by the action of the deterioration processes. 
Table 2: Mean, maximum, and minimum deterioration index ( \pm standard deviation) and density of the thermally-modified pine wood, non-impregnated and nano-ZnO impregnated, after five months in field tests.

\begin{tabular}{|c|c|c|c|c|c|}
\hline \multirow{2}{*}{$\begin{array}{c}\text { Nanoparticle } \\
\text { treatment }\end{array}$} & $\begin{array}{c}\text { Temperature } \\
\left({ }^{\circ} \mathrm{C}\right)\end{array}$ & \multicolumn{3}{|c|}{ Deterioration index } & \multirow{2}{*}{$\begin{array}{c}\text { Density } \\
\left(\mathrm{kg} / \mathrm{m}^{3}\right)\end{array}$} \\
\cline { 2 - 6 } & Control & $43 \pm 26$ & 70 & 0 & 700 \\
\cline { 2 - 6 } & 180 & $23 \pm 36$ & 70 & 0 & 760 \\
\cline { 2 - 6 } $\begin{array}{c}\text { Non- } \\
\text { impregnated }\end{array}$ & 200 & $30 \pm 35$ & 70 & 0 & 740 \\
\cline { 2 - 6 } & 220 & $45 \pm 12$ & 70 & 40 & 610 \\
\hline \multirow{4}{*}{$\begin{array}{c}\text { nano-ZnO } \\
\text { impregnated }\end{array}$} & Control & $68 \pm 16$ & 90 & 40 & 710 \\
\cline { 2 - 6 } & 180 & $7 \pm 16$ & 40 & 0 & 710 \\
\cline { 2 - 6 } & 200 & $37 \pm 31$ & 70 & 0 & 730 \\
\cline { 2 - 6 } & 220 & $47 \pm 41$ & 100 & 0 & 660 \\
\hline
\end{tabular}

The analysis of the mass loss caused mainly by termites is an important variable to verify the improvement or not of biological resistance to the wood by the treatment. In this sense, it was observed that the nano- $\mathrm{ZnO}$ impregnated-unmodified samples and the non-impregnated-220 ${ }^{\circ} \mathrm{C}$-modified samples had lower mass losses (Figure 2). The mass loss assessment must be carried out together with that of the wood density in order to avoid misinterpretations. The temperature at $200^{\circ} \mathrm{C}$ decreased the density of the wood, (Table 2) and when a non-toxic substrate has a lower density, the termites may remove a similar amount of biomass as a denser substrate, however, the lesions caused by this removal may be more significant. This may explain the similar mass loss recorded for the nano-ZnO-impregnated-unmodified and $220^{\circ} \mathrm{C}$-modified samples.

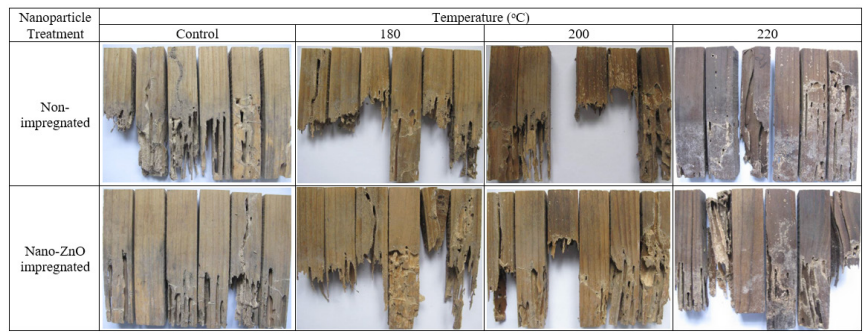

Figure 1: Deterioration of the thermally-modified pine wood, non-impregnated and nano-ZnO impregnated, after five months in field tests.

This fact is evident when the mass loss of the wood is analyzed together with the deterioration index, which is a value that expresses, among other attributes, the lesions provided by the xylophagous organisms in the wood. Thus, although the mass losses were equivalent in the nano-ZnO-impregnated-unmodified and $220^{\circ} \mathrm{C}$-modified samples, the deterioration index shows that the thermally-modified samples had higher wear caused by xylophages, compared to the nano-ZnO-impregnated-unmodified samples (Table 2).

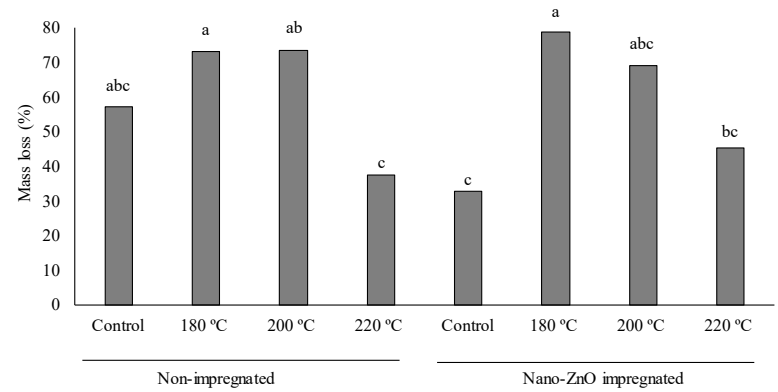

Figure 2: Relative mass loss of the thermally-modified pine wood, non-impregnated and nano-ZnO impregnated, after five months in field tests.

Means with the same letter are not significantly different from each other by Tukey's test at the 0,05 probability level. 
Therefore, the nano- $\mathrm{ZnO}$ impregnation in the natural pine wood is more efficient to improve biological resistance than when added to thermally-modified wood at $220^{\circ} \mathrm{C}$, which exhibited more evident lesions provided by xylophages. A study realized by Clausen et al. (2009) reported the effectiveness of nano-ZnO treatment to prevent the consumption of wood by termites, regardless of the size of the nanoparticles. These authors also reported significant mortality of termites at a nano- $\mathrm{ZnO}$ concentration of $1 \%$. However, it must be considerate that they performed laboratory trials that promote constant conditions and the termites have no preference choice.

It is important to consider other factors that influence the deterioration of wood by xylophages in field tests, including abiotic factors such as $\mathrm{pH}$. The $\mathrm{pH}$ of the soil may influence the properties of the nanoparticles, which can be solubilized at very acid or very basic $\mathrm{pH}$. Thus, the high mortality of termites observed in other studies (Clausen et al. 2011), may not occur under conditions that favor the solubility of the nanoparticles as in field conditions. In addition, the presence of water and the acidic $\mathrm{pH}$ of the wood could promote the dissolution of the nano- $\mathrm{ZnO}$ (Silva 2018). Therefore, in field tests, soil moisture and precipitation may favor leaching. Clausen et al. (2010) evaluated the leach resistance of the Southern pine samples vacuum-treated with nano-ZnO. In laboratory tests, no leaching occurred in nano-ZnO-treated samples even at the highest retention of $12,96 \% \mathrm{~kg} / \mathrm{m}^{3}$ with a concentration of $5 \%$. However, in the field experiments, the authors found a loss of nano- $\mathrm{ZnO}$ by leaching of $65 \%$ in concentrations of 2,5\% and $58 \%$ in the concentration of $5 \%$. Low concentrations of nano- $\mathrm{ZnO}(1 \%)$ showed almost no leaching, however, these authors did not report the $\mathrm{pH}$ in which the samples were tested. Lykidis at al. (2018) assessed wood species Fagus sylvatica impregnated with nano- $\mathrm{ZnO}$, at the concentrations of $0,5 \%, 1 \%, 2 \%$, and observed that all treatments increased its resistance to the action of termite species Reticulitermes grassei; leaching by water did not significantly change this result.

Our results show that, even with these assumptions, the nano- $\mathrm{ZnO}$ impregnation improved biological resistance to natural pine wood at low concentration. Clausen et al. (2011) used an aqueous dispersion containing three nano- $\mathrm{ZnO}$ concentrations $(1,0 \% ; 2,5 \%$ and $5,0 \%)$ to treat Southern yellow pine and assess the termite mortality in laboratory tests. Their results showed that termite (Reticulitermes flavipes) consumed less than $10 \%$ and exhibited from $93 \%$ to $100 \%$ mortality for all treatment concentrations. Thus, it is possible to assume that, under field conditions, higher concentrations could result in less mass loss and greater resistance to xylophages. According to Mantanis et al. (2014), nano-ZnO has shown reduced leaching when it was incorporated, in association with acrylic emulsion, to pine wood. Thus, this type of emulsion can be an interesting strategy to reduce the leaching of these nanoparticles under field conditions.

The size of nanoparticles also can be an important factor for the efficacity of the treatment. Kartal et al. (2009) reported good efficiency of nano- $\mathrm{ZnO}$ treatment of Southern yellow pine wood against Eastern subterranean termites (Reticulitermes flavipes) and decay fungi using nanoparticles from $40 \mathrm{~nm}$ to $100 \mathrm{~nm}$. Németh et al. (2013) also reported good performance of nano-ZnO of 20-40 nm in the resistance of some softwoods and hardwoods (spruce (Picea abies L.), Scots pine sapwood (Pinus sylvestris L.), poplar (Populus $x$ euramericana cv. Pannonia), and beech (Fagus sylvatica L.) species using concentration of $5 \%$. On the other hand, Lykidis et al. (2016) evaluated the resistance of Scots pine wood treated with nano-ZnO of 60-80 $\mathrm{nm}$ against the brown-rot fungi (Daedalea quercina L. and Poria placenta (Fr.) Cooke) and dry rot fungus (Serpula lacrymans (Wulfen) J. Schröt.). The nano-ZnO treatment improved the wood resistance to Serpula lacrymans but not against the Poria placenta fungus. Clausen et al. (2011) used nano-ZnO of $30 \mathrm{~nm}$ and 70 $\mathrm{nm}$, but they did not evaluate its efficacity against fungi. Furthermore, these studies show that nano- $\mathrm{ZnO}$ efficacity also depends on the wood and the xylophage species.

Also, the efficiency of nano-ZnO was observed for wood-based composites. Marzbani et al. (2015) also studied the effect of nano-ZnO added to the adhesive urea-formaldehyde used in the manufacture of particleboard against the white-rot (Trametes versicolor (L.) Lloyd) and the brown-rot (Coniophora puteana (Schumach.) P. Karst.) fungi. The authors added $5 \%, 10 \%$ and $15 \%$ of nano- $\mathrm{ZnO}$ (based on the dry weight of the adhesive). Their results showed an improvement of particleboard against fungi decay, principally at 15\% nano-ZnO. Taghiyari et al. (2015) observed that wood species Paulownia subjected to heat treatment at $150{ }^{\circ} \mathrm{C}$, in association with nano-ZnO impregnation under laboratory conductions, significantly inhibited the growth of fungus species Trametes versicolor and the loss of mass.

In order to evaluate the efficiency of a product and/or process to preserve wood against the action of xylophagous organisms, mainly termites, several parameters should be considered and not only the mass loss. The foraging and tunneling pattern of termites can provide important information about the influence of these treatments on the biological resistance and consequently on their preservative efficiency in the wood. Therefore, the occurrence of tunnels in the aerial part of the samples caused by two subterranean termite 
species: Coptotermes gestroi (Wasmann) and Heterotermes tenuis (Hagen) was registered monthly during the five months in the field conditions (Figure 3). According to Guadalupe-Rojas and Morales-Ramos (2001), the food preference of Coptotermes formosanus Shiraki is determined by the nutritional value of the resource. Considering that this is the same for other termite species, tunnel construction time, analyzed together with the mass loss and the lesions caused in the samples, may reveal relevant information to evaluate the efficiency of wood preservation techniques. Therefore, termites choose their food according to nutritional needs, and for this choice to take place, it is necessary to construct tunnels to locate suitable food resources (Grace and Campora 2005). Food is only accepted after arduous inspection by fodder since not all sources are accepted (Lima 2014). This inspection occurs by foraging the substrate, which occurs when the termite constructs the tunnels on the substrate.

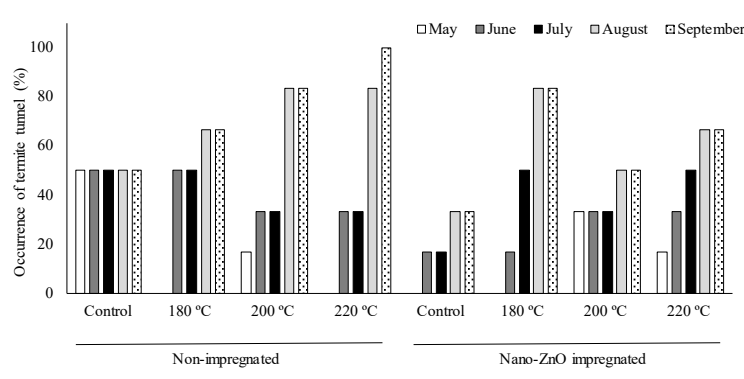

Figure 3: Percentage occurrence of termite tunnels in thermally-modified pine wood, non-impregnated and nano-ZnO impregnated, after five months in field tests.

Our results showed that the majority of the non-impregnated samples had a greater occurrence of tunnels in the external part of the sample (Figure 3). This fact could suggest that biomass consumption was higher in these samples. However, the external tunneling of the samples only shows that the resource is being foraged and not effectively consumed by the termites. Lima (2014) explains the importance of analyzing the tunneling pattern together with the biomass values consumed as well as associating them with the lesions caused by the insects in the samples. In our study, the occurrence of tunnels was evaluated by the system of grades attributed to wear by the termite (Table 1). All the non-impregnated-220 ${ }^{\circ} \mathrm{C}$-modified samples presented the occurrence of tunnels at the final of the experiment (Figure 3), however, they exhibited low mass loss, together with the nano-ZnO-impregnated-unmodified samples (Figure 2). This suggests that the non-impregnated-220 ${ }^{\circ} \mathrm{C}$-modified samples, although the higher occurrence of tunnels, had only foraging by termites, not consumption effectively. Hence, the thermal modification at $220^{\circ} \mathrm{C}$ can add characteristics that make the wood little palatable to these insects and not necessarily toxic. This could justify the greater presence of tunnels in these samples, which would be more difficult to produce if the substrate were toxic. On the other hand, the nano-ZnO-impregnated-unmodified samples were discarded at the beginning and consequently had lower occurrence tunnels to the end of the experiment (Figure 3), indicating the toxic effect of the nanoparticles. These results corroborate to those found by Clausen et al. (2011), which showed high mortality and low mass consumption by Reticulitermes flavipes termite in nano-ZnO-treated samples.

Considering these data, we found that the thermal modification at $180{ }^{\circ} \mathrm{C}$ and $200{ }^{\circ} \mathrm{C}$, even with the nano- $\mathrm{ZnO}$ treatment, made the wood more attractive and consumed by termites. Nevertheless, the temperature of $220^{\circ} \mathrm{C}$ made the wood attractive but less consumed by the termites. The nano- $\mathrm{ZnO}$ incorporation to unmodified wood was the most efficient treatment for wood preservation since these samples were the least tunneled and less consumed by termites. However, the nano- $\mathrm{ZnO}$ incorporation to the thermally-modified wood was not efficient to improve the deterioration resistance under the conditions of the field test.

\section{CONCLUSIONS}

The nano- $\mathrm{ZnO}$ impregnation increase the degradation resistance in unmodified Caribbean pine wood, however, it does not improve the degradation resistance of $180{ }^{\circ} \mathrm{C}$ and $200{ }^{\circ} \mathrm{C}$-modified samples.

The $220^{\circ} \mathrm{C}$-modified Caribbean pine samples were more resistant to xylophage organisms, regardless of the nano-ZnO impregnation, compared to unmodified, $180{ }^{\circ} \mathrm{C}$ and $200{ }^{\circ} \mathrm{C}$-modified samples. 
Pinus wood impregnated with nano- $\mathrm{ZnO}$ has shown decreased tunneling by termites under natural conditions, which indicated anti-feeding effect on these organisms.

Nano-ZnO impregnation in pine wood is a promising treatment to add biological resistance to this material under field conditions. It is necessary to conduct further studies to assess the efficiency of this technique in other forest species, as well as to investigate its application in association with other procedures that also aim at protecting this material from biological deterioration processes.

\section{ACKNOWLEDGMENTS}

This work was conducted during a scholarship supported by CAPES - Brazilian Federal Agency for Support and Evaluation of Graduate Education within the Ministry of Education of Brazil. The authors are grateful to Professor Dr. Bernard Riedl of the Laval University of Canada for his valuable guidance on the treatment of nanoparticles.

\section{REFERENCES}

Ayres, M.; Ayres, M.; Ayres, D.L.; Santos, A.A.A. 2007. BioEstat 5.0. Aplicações Estatísticas nas Áreas das Ciências Biológicas e Médicas. Tefé: Sociedade Civil Mamirauá.Brazil.

Bak, M.; Németh, R. 2018. Effect of different nanoparticle treatments on the decay resistance of wood. BioResources 13(4): 7886-7899. https://ojs.cnr.ncsu.edu/index.php/BioRes/article/view/BioRes_13_4_7886_ Bak_Nanoparticle_Decay_Resistance_Wood.

Clausen, C.A.; Green, F.; Nami Kartal, S. 2010. Weatherability and leach resistance of wood impregnated with nano-zinc oxide. Nanoscale Res Lett 5(9): 1464-1467. https://doi.org/10.1007/s11671-010-9662-6

Clausen, C.A.; Kartal, S.N.; Arango, R.A.; Green, F. 2011. The role of particle size of particulate nano-zinc oxide wood preservatives on termite mortality and leach resistance. Nanoscale Res Lett 6: 427. https://doi.org/10.1186/1556-276X-6-427

Clausen, C.A.; Yang, V.W.; Arango, R. A.; Green, F. 2009. Feasibility of nanozinc oxide as a wood preservative. In Proceedings of American Wood Protection Association 105: 255-260. https://naldc.nal.usda.gov/download/41044/PDF

Grace, J.K.; Campora, C.E. 2005. Food location and discrimination by subterranean termites (Isoptera: Rhinotermitidae). In Proceedings of International Conference on Urban Pests 437-441

Guadalupe-Rojas, M.; Morales-Ramos, J.A. 2001. Bait matrix for delivery of chitin synthesis inhibitors to the Formosan subterranean termite (Isoptera: Rhinotermitidae). $J$ Econ Entomol 94(2): 506-510. https://doi.org/10.1603/0022-0493-94.2.506

Kartal, S.N.; Green III, F.; Clausen, C.A. 2009. Do the unique properties of nanometals affect leachability or efficacy against fungi and termites? Inter Biodeter Biodegr 63(4): 490-495. https://doi.org/10.1016/j.ibiod.2009.01.007

Lepage, E.S. 1970. Método Sugerido pela IUFRO para ensaios de campo com estacas de madeira. Preservação de madeiras 1: 205-216

Lima, J.T.; Costa-Leonardo, A.M. 2014. Foraging in subterranean termites (Isoptera: Rhinotermitidae): how do Heterotermes tenuis and Coptotermes gestroi behave when they locate equivalent food resources? $B$ Entomol Res 10(4): 525-533. https://doi.org/10.1017/S0007485314000297

Lykidis, C.; Bak, M.; Mantanis, G.; Németh, R. 2016. Biological resistance of pine wood treated with nano-sized zinc oxide and zinc borate against brown-rot fungi. Eur J Wood Wood Prod 74(6): 909-911. https://doi.org/10.1007/s00107-016-1093-3

Lykidis, C.; Mantanis, G.; Adamopoulos, S.; Kalafata, K. 2013. Arabatzis, I. Effects of nano-sized zinc oxide and zinc borate impregnation on brown rot resistance of black pine (Pinus nigra L.) wood. Wood Mater 
Sci Eng 8(4): 242-244. https://doi.org/10.1080/17480272.2013.834969

Lykidis, C.; Troyab, T. De.; Condeb, M.; Galvánc, J.; Mantanisd, G. 2018. Termite resistance of beech wood treated with zinc oxide and zinc borate nanocompounds. Wood Mater Sci Eng 13(1): 45-49. https://doi.org/10.1080/17480272.2016.1257651

Mantanis, G.; Terzi, E.; Kartal, S.N.; Papadopoulos, A.N. 2014. Evaluation of mold, decay and termite resistance of pine wood treated with zinc- and copper-based nanocompounds. Int Biodeter Biodegr 90: 140144. https://doi.org/10.1016/j.ibiod.2014.02.010

Marzbani, P.; Afrouzi, Y.; Omidvar, A. 2015. The effect of nano-zinc oxide on particleboard decay resistance. Maderas-Cienc Tecnol 17(1): 63-68. http://dx.doi.org/10.4067/S0718-221X2015005000007

Németh, R.; Bak, M.; Yimmou, B.M.; Csupor, K.; Molnár, S.; Csóka, L. 2013. Nano-zink as an agent against wood destroying fungi. In Wood the Best Material for Mankind. Kúdela, J.; Babiak, M. (eds). Arbora Publishers, Zvolen, Slovakia. https://iaws-web.org/files/file/Zborn\%C3\%ADk\%202012.pdf

Paes, J.B.; Segundinho, P.G.A.; Euflosino, A.E.R.S.; Oliveira, J.G.L. 2015. Resistance of thermally treated woods to Nasutitermes corniger in a food preference test. Madera Bosques 21(1): 157-164. https://doi.org/10.21829/myb.2015.211439

Pessoa, A.M.C.; Berti Filho, E.; Brito, J.O. 2006. Evaluation of the Eucalyptus grandis thermorectificated wood submitted to the drywood termite attack, Cryptotermes brevis. Sci For 72: 11-16. https://www.ipef.br/publicacoes/scientia/nr72/cap01.pdf

Salman, S.; Thévenon, M.F.; Pétrissans, A.; Dumarçay, S.; Candelier, K.; Gérardin, P. 2017. Improvement of the durability of heat-treated wood against termites. Maderas-Cienc Tecnol 19(3): 317-328. http://dx.doi.org/10.4067/S0718-221X2017005000027

Silva, B. C. 2018. Efeitos da modificação térmica e da impregnação de nanopartículas na molhabilidade da superfície, composição química e na deterioração da madeira de pinus. Ph.D Thesis, Federal Rural University of Rio de Janeiro, UFRRJ. Rio de Janeiro, Brazil (not published)

Sivrikaya, H.; Can, A.; Troya, T.; Conde, M. 2015. Comparative biological resistance of differently thermal modified wood species against decay fungi, Reticulitermes grassei and Hylotrues bajulus. MaderasCienc Tecnol 17(3): 559-570. http://dx.doi.org/10.4067/S0718-221X2015005000050

Taghiyari, H.R.; Kalantari, A.; Ghorbani, M.; Bavaneghi, F.; Akhtari, M. 2015. Effects of fungal exposure on air and liquid permeability of nanosilverand nanozincoxide-impregnated Paulownia wood. Int Biodeter Biodegr 105: 51-57. https://doi.org/10.1016/j.ibiod.2015.08.014

Trevisan, H.; Latorraca, J.V.F.; Santos, A.L.P.; Teixeira, J.G.; Carvalho, A.G. 2014. Analysis of rigidity and deterioration from exposure in a decay test field of thermorectificated Eucalyptus grandis wood. Maderas-Cienc Tecnol 16(22): 217-226. http://dx.doi.org/10.4067/S0718-221X2014005000017

Tripathi, S.; Pant, H.; Kashyap, A.K. 2014. Decay resistance against Basidiomycetes fungi of hart-treated Pinus roxburghii and Mangifera indica wood. J Trop For Sci 26(2): 203-207. https://www.jstor.org/stable/23723905?seq=1

Valle, M.L.A.; Silva, J.C.; Della Lucia, R.M.; Evangelista, W.V. 2013. Retention and penetration of CCA in wood of first and second rotation of Eucalyptus urophylla S.T. Blake. Cienc Florest 23(2): 481-490. https://doi.org/10.5902/198050989292

Vidal, J.M.; Evangelista, W.V.; Silva, J.C.; Jankowsky, I.P. 2015. Preservação de madeiras no Brasil: histórico, cenário atual e tendências. Cienc Florest 25(1): 257-271. https://www.scielo.br/scielo.php?pid=S1980-50982015000100257\&script=sci_arttext\&tlng=pt 